\title{
The determinants of tax revenue and tax effort in developed and developing countries: theory and new evidence 1996-2015
}

Os determinantes da receita tributária e do esforço tributário em países desenvolvidos e em desenvolvimento: teoria e novas evidências 1996-2015

\author{
Marcelo Piancastelli (1) \\ A.P. Thirlwall (2) \\ (1) Institute for Applied Economic Research (IPEA) \\ (2) University of Kent
}

\section{Abstract}

This paper measures the tax effort of a group of fifty-nine developed and developing countries over the period $1996-2015$ by comparing a country's actual tax/GDP ratio with the ratio predicted derived from an international tax function which relates tax revenue to various measures of a country's taxable capacity such as the level of per capita income; the share of trade in GDP; the productive structure, and the level of financial deepening. The tax function is estimated using cross section data; pooled time series/cross section data, and panel data using a fixed effects estimator. The results are compared and show a range of tax effort from South Africa with the highest effort and Switzerland with the lowest effort. Implications for policy are drawn. The paper is critical of studies that include institutional variables (and other variables not related to the tax base of countries) to measure tax effort when they are really explanations of why the tax ratio differs between countries not of tax effort itself.

\section{Keywords}

tax ratios, tax effort.

JEL Codes H2.

\section{Resumo}

Este trabalho estima o esforço fiscal de um grupo de cinquenta e nove países desenvolvidos e em desenvolvimento para o periodo 1996-2015, pela comparação da relação receita tributária atual e PIB (Produto Interno Bruto) e a mesma relação estimada e derivada de uma função tributária internacional. Esta função relaciona a receita tributária a várias medidas da capacidade tributária e um país, tais como o nivel da renda per capita; a participação do comércio no PIB, a estrutura produtiva, e o nivel de intermediação financeira. A função tributária é estimada usando dados cross-section; séries de tempo e cross-section interpolada e painel de dados com efeitos fixos. Os resultados são comparados e mostram uma amplitude de esforço fiscal entre países. Implicações para politicas são então apresentadas. O trabalho critica os estudos que incluem variáveis institucionais e outras não relacionadas com a base fiscal para se estimar o esforço fiscal, pois na verdade são explicações dos motivos pelos quais relações tributárias diferem entre países, não o esforço fiscal par si próprio.

\section{Palavras-chave}

alíquotas tributárias, esforço tributário.

Códigos JEL $H 2$. 


\section{Introduction}

Almost all countries - both developed and developing - require more tax revenue for the provision of public goods and for tackling poverty. Spending on infrastructure, public utilities, health and education all depend on raising tax revenue in sufficient quantities (Kaldor, 1963; IMF, 2011). Without it, governments must borrow which increases public debt, and may cause fiscal crisis in the future if debt becomes too high as a proportion of gross domestic product (GDP), and countries find difficulty in repaying. As Bird (1975) says 'even if one does not accept the simple capital formation model of development - - - it seems clear that no poor country can get very far without in some sense "mobilising" more resources, at least to some degree through taxation'. Likewise, Burgess and Stern (1993) remark 'debt and money finance often prove to be unsustainable sources of revenue and in the long run there is no real substitute for taxation'. Cody (2018) has recently reiterated the point more explicitly: 'a key challenge for developing economies wishing to strengthen their social protection systems and expand access to education and health is how to raise the necessary revenue in the context of a large informal sector'. Lewis (1966) in his book Development Planning was far too cautious when he said 'most underdeveloped countries need to raise at least 17 percent of gross domestic product in taxes and other government revenue, taking central and local authorities together'. Tax revenue in most developing countries is now higher than that and there are still considerable unmet expenditure needs. Moore, Prichard and Fjeldstad (2018) highlight the situation in Africa where the ratio of tax to GDP has increased in recent years to an average of 18 percent. Yet the revenues fall far short of spending needs. As the authors say 'so much more needs to be done'. Unfortunately in Africa, and elsewhere, tax authorities are up against powerful vested interests that obstruct tax reform.

Table 1 below gives the tax ratio and the total government debt to GDP ratio for a selection of forty-two developing countries in 2010 and 2016, compared to a sample of twenty-six developed countries for the same years. It can be seen that the tax ratio for developing countries is much lower than for developed countries. The average 'tax take' of developing countries in 2016 was 20.4 percent compared with 33.4 percent in developed countries. It can also be seen that the debt ratio is lower, reflecting the difficulty that poor countries have to access capital markets and bor- 
row to finance government expenditure. Countries in real difficulty would be countries with a relatively low tax ratio and a relatively high debt ratio. From our sample of countries here, countries such as Ghana, India, Malaysia, Mexico, Pakistan, Sierra Leone and Sudan would appear to be in particular trouble. One of the things we shall explore later is whether the tax effort of some of these countries is 'good' or 'bad', and if the latter, how the tax ratio might be raised.

The basic question we shall be trying to answer is whether the tax ratio is lower in developing countries because the tax base is lower, or whether the developing countries are not making as much tax effort as they could, either because they apply low tax rates or allow far too much tax evasion and tax avoidance. One of the ways of addressing this issue, first developed by Lotz and Morss $(1967)^{1}$ at the IMF, is to estimate a tax revenue equation across countries, in which tax revenue as a percent of GDP (or tax ratio) is made a function of various tax bases and the structural characteristics of countries, such as per capita income; the share of trade in GDP, and the shares of agriculture, industry and services in GDP, and then to compare the actual tax ratio of each country to the tax ratio predicted by the equation, taking values of the various independent variables for each individual country. The difference between the actual tax ratio and that predicted gives a measure of tax effort. Pooled time series/cross section data, panel data, or cross section data can be used for estimation of predicted tax revenue.

Work of this type is not without its critics, but in our view many of the criticisms are not justified. Bird (1975), for example, makes two major objections (apart from the fact that the data used for estimation may be unreliable). First, he argues that there is no a priori justification for the use of the selected variables as a measure of taxable capacity. In the case of per capita income, for example, as a determinant of tax revenue, he says "presumably it is included because it is a proxy for a potentially higher tax base, or a larger "taxable surplus", [but] income is surely as much a "demand" as it is a "supply" factor: the identification problem seems insuperable in this respect'. By "demand" Bird means the willingness to tax, and he makes the same argument with respect to other variables (as well as per capita income) such as the share of trade, agriculture and mining in GDP. 1 And others subsequently by Shin (1969); Bahl (1971); Chelliah et al. (1975); Tait et al. (1979); Piancastelli (2001). 
He goes on "the distinction between capacity and willingness is a terribly fuzzy one: indeed, one might say that "capacity" without "willingness" is not really "capacity" - or "effective capacity", if I may coin a term - at all'. This is far too iconoclastic. If the capacity is there, measured by variables such as per capita income and the structural characteristics of countries, but the willingness to tax is low, this is exactly what leads to a low tax effort. A lack of willingness is a lack of effort.

A second objection of Bird (1975) is that since the estimation of tax revenue comes from cross section or panel data, inferences cannot be drawn for individual countries. He states that there is no meaningful sense in which the average experience measured by cross section analysis can be considered as a standard of comparison' - - 'undue attention to such international comparisons is more likely to detract from, than illuminate, the needed analysis of problems and policies in individual developing countries'. Again, we believe this is far too iconoclastic. While it may be true that a country with an actual tax ratio above that predicted from the cross section equation is because a variable has been missed from the equation determining the actual tax ratio (which may be important for an individual country), the opposite is extremely unlikely that a country with an actual tax ratio below predicted is making a good tax effort, and that there is not scope for improvement based on taxing individuals, trade or sectors of the economy, more heavily. Thus, it is hard to agree with Bird's central conclusion that 'there is no merit at all in the contention that differences between predicted and actual values - - - measure in any meaningful way the scope for change in a particular country, or the gap that can (or should) be closed through additional "effort"'.

Table 1 Tax and debt ratios of developing and developed countries

\begin{tabular}{l|rr|r|r}
\hline $\begin{array}{l}\text { Developing } \\
\text { Countries }\end{array}$ & \multicolumn{2}{|r|}{$\begin{array}{r}\text { Total Tax } \\
\text { Revenue }\end{array}$} & \multicolumn{2}{r}{$\begin{array}{r}\text { Total Gov. } \\
\text { Debt }\end{array}$} \\
\cline { 2 - 5 } & $\mathbf{2 0 1 0}$ & $\mathbf{2 0 1 6}$ & $\mathbf{2 0 1 0}$ & $\mathbf{2 0 1 6}$ \\
\hline Argentina & 21.1 & 21.4 & 42.0 & 53.3 \\
\hline Belize & 27.3 & 26.6 & 80.2 & 76.6 \\
\hline Bolivia & 23.3 & 34.7 & 37.6 & 46.2 \\
\hline Botswana & 36.3 & 33.5 & 21.6 & 15.2 \\
\hline Brazil & 28.8 & 29.5 & 61.3 & 73.5 \\
\hline
\end{tabular}

\begin{tabular}{l|r|r|r|r}
\hline $\begin{array}{l}\text { Developed } \\
\text { Countries }\end{array}$ & \multicolumn{2}{|c|}{$\begin{array}{r}\text { Total Tax } \\
\text { Revenue }\end{array}$} & \multicolumn{2}{r}{$\begin{array}{r}\text { Total Gov. } \\
\text { Debt }\end{array}$} \\
\cline { 2 - 5 } & $\mathbf{2 0 1 0}$ & $\mathbf{2 0 1 6}$ & $\mathbf{2 0 1 0}$ & $\mathbf{2 0 1 6}$ \\
\hline Australia & 23.3 & 24.8 & 29.3 & 40.7 \\
\hline Austria & 43.5 & 44.1 & 82.4 & 83.7 \\
\hline Belgium & 40.1 & 38.6 & 99.7 & 105.7 \\
\hline Canada & 16.9 & 17.4 & 81.1 & 91.1 \\
\hline Denmark & 39.9 & 39.2 & 42.6 & 37.7 \\
\hline
\end{tabular}

(continues on the next page) 
Table 1 (continuation)

\begin{tabular}{|c|c|c|c|c|}
\hline \multirow[t]{2}{*}{$\begin{array}{l}\text { Developing } \\
\text { Countries }\end{array}$} & \multicolumn{2}{|c|}{$\begin{array}{l}\text { Total Tax } \\
\text { Revenue }\end{array}$} & \multicolumn{2}{|c|}{$\begin{array}{r}\text { Total Gov. } \\
\text { Debt }\end{array}$} \\
\hline & 2010 & 2016 & 2010 & 2016 \\
\hline Cameroon & 16.5 & 18.2 & 14.7 & 31.5 \\
\hline Chile & 21.4 & 20.8 & 8.6 & 21.0 \\
\hline Colombia & 21.5 & 24.2 & 72.3 & 58.0 \\
\hline Congo, D R & 14.3 & 13.5 & 30.9 & 16.8 \\
\hline Costa Rica & 23.1 & 24.8 & 28.3 & 44.9 \\
\hline Dominican $\mathrm{R}$ & 13.8 & 15.6 & 23.7 & 35.0 \\
\hline Egypt & 24.8 & 21.0 & 85.8 & 96.8 \\
\hline El Salvador & 22.0 & 24.0 & 57.5 & 52.7 \\
\hline Fiji & 24.0 & 27.6 & 56.2 & 46.5 \\
\hline Ghana & 17.5 & 19.4 & - & 73.4 \\
\hline Guatemala & 11.1 & 11.0 & 24.4 & 22.1 \\
\hline India & 13.3 & 12.6 & 52.2 & 50.3 \\
\hline Indonesia & 14.5 & 12.5 & 26.2 & 31.4 \\
\hline Iran & 25.4 & 16.0 & 11.7 & 48.9 \\
\hline Jordan & 31.0 & 23.8 & 67.1 & 95.1 \\
\hline Kenya & 19.8 & 20.1 & 44.4 & 53.5 \\
\hline Madagascar & 11.9 & 13.6 & 31.7 & 38.4 \\
\hline Malaysia & 19.4 & 17.3 & 49.6 & 52.7 \\
\hline Mauritius & 22.1 & 22.8 & 36.8 & 60.1 \\
\hline Mexico & 18.0 & 19.8 & 42.3 & 56.8 \\
\hline Morocco & 31.0 & 26.8 & 50.9 & 64.7 \\
\hline Namibia & 28.3 & 30.6 & 16.9 & 23.1 \\
\hline Nepal & 14.9 & 21.6 & 33.9 & 27.3 \\
\hline Pakistan & 13.8 & 11.0 & 60.6 & 67.6 \\
\hline Panama & 23.5 & 20.1 & 38.6 & 37.1 \\
\hline Paraguay & 19.9 & 22.2 & 15.6 & 24.9 \\
\hline Peru & 20.3 & 18.1 & 23.7 & 23.2 \\
\hline Philippines & 13.4 & 15.2 & 52.4 & 45.4 \\
\hline Sierra Leone & 9.8 & 9.8 & 46.8 & 54.9 \\
\hline South Africa & 28.1 & 30.9 & 26.0 & 51.6 \\
\hline Sudan & 19.3 & 9.8 & 64.4 & 91.4 \\
\hline Thailand & 19.0 & 20.0 & 26.9 & 35.3 \\
\hline
\end{tabular}

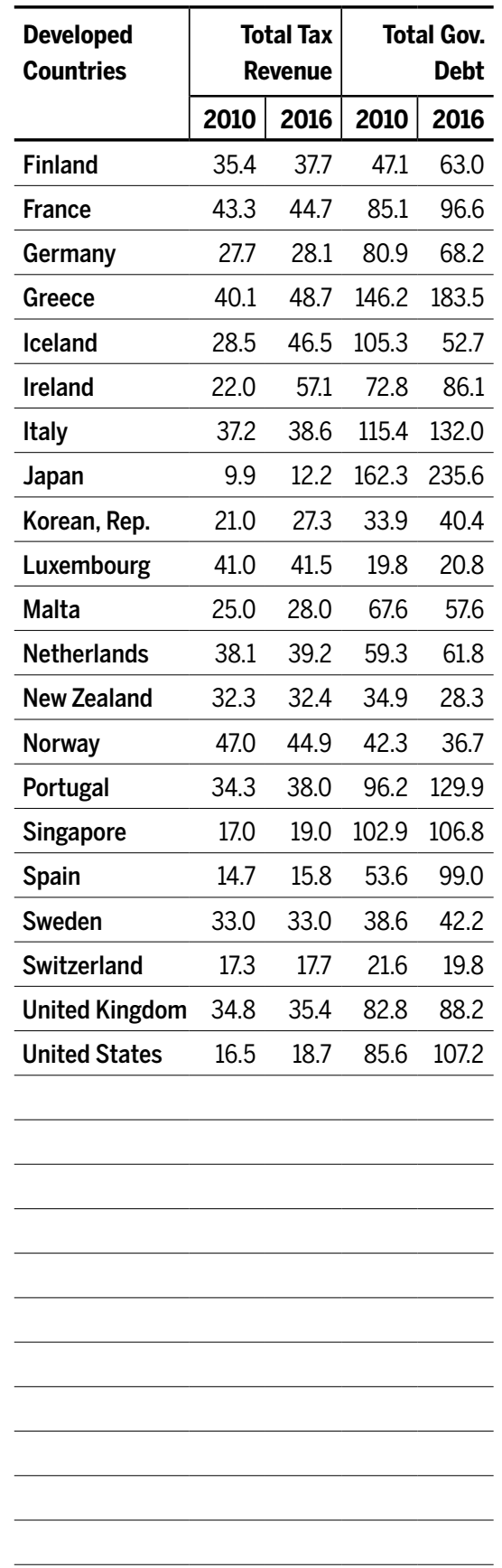

(continues on the next page) 
Table 1 (continuation)

\begin{tabular}{|c|c|c|c|c|c|c|c|c|c|}
\hline \multirow[t]{2}{*}{$\begin{array}{l}\text { Developing } \\
\text { Countries }\end{array}$} & \multicolumn{2}{|c|}{$\begin{array}{l}\text { Total Tax } \\
\text { Revenue }\end{array}$} & \multicolumn{2}{|c|}{$\begin{array}{r}\text { Total Gov. } \\
\text { Debt }\end{array}$} & \multirow[t]{2}{*}{$\begin{array}{l}\text { Developed } \\
\text { Countries }\end{array}$} & \multicolumn{2}{|c|}{$\begin{array}{l}\text { Total Tax } \\
\text { Revenue }\end{array}$} & \multicolumn{2}{|c|}{$\begin{array}{r}\text { Total Gov. } \\
\text { Debt }\end{array}$} \\
\hline & 2010 & 2016 & 2010 & 2016 & & 2010 & 2016 & 2010 & 2016 \\
\hline Tunisia & 29.0 & 14.9 & 40.7 & 61.2 & & & & & \\
\hline Turkey & 31.7 & 33.1 & 47.4 & 31.9 & & & & & \\
\hline Uruguay & 29.9 & 36.1 & 44.2 & 50.7 & & & & & \\
\hline Venezuela & 21.2 & 15.7 & 36.5 & 31.3 & & & & & \\
\hline Zambia & 13.9 & 18.1 & 18.0 & 49.4 & & & & & \\
\hline
\end{tabular}

Source: International Monetary Fund; GFS Yearbook and data files; World Bank and OECD GDP estimates. Updated 08.28.2018.

N.B All figures as a percentage of GDP .

\section{Tax effort - literature review}

This study will take the traditional approach to the measurement of tax effort, but with some differences compared to previous studies. First, all the variables will be measured in logarithms. This has the advantage of narrowing the variance in the data and enables a comparison of elasticities (or impact) of the different independent variables on tax revenue as a proportion of GDP. Secondly, we pay more attention to the structure of economies by including in the regression equations not only the share of the agricultural sector in GDP (as is common in most studies), but also the share of industry and services, separately and together. Thirdly, we test the hypothesis that the degree of monetisation of an economy may make a difference to tax revenue because this is likely to be associated with a larger volume of money-based transactions and a more efficient way of quantifying the size of various tax bases. ${ }^{2}$ Finally, we shall use three different estimation methods to compare results and their robustness.

We shall deliberately exclude political and institutional variables such as corruption, civil liberties, political stability etc. which have been used in some recent studies (e.g. Le et al., 2012 and Dioda, 2012) for a very important reason. The measurement of tax effort should be related to how the which seems implausible. Rodriguez (2018) takes a broader definition of financial intermediation and finds it significant particularly for low-income countries. 
tax bases of a country are being exploited, not to the institutional and political environment because if these variables are significant in determining tax revenue, the measurement of tax effort, measured as the ratio of actual tax revenue to predicted revenue, will paradoxically fall because predicted revenue from cross section or panel data studies will rise. Studies by Le et al. (2012) and Dioda (2012) do not recognise this fundamental point when they use their comprehensive studies of the determinants of tax revenue to measure tax effort. A clear distinction needs to be made between the capacity to tax and the success in exploiting this capacity. Studies of tax effort should focus on the tax bases of countries including the structure of economies, and separate studies can be undertaken of why tax effort differs between countries.

We take for analysis a sample of 59 developed and developing countries over the period 1996 to 2015 chosen on the basis of a consistent data set for all the variables we include. We employ various econometric techniques including pooled time series/cross section estimation, OLS cross section, and panel data analysis to compare results and to check for robustness. We choose the most satisfactory results to give a ranking of the tax effort of our sample of countries, and end with some policy conclusions. But first let us survey some previous studies.

\subsection{Survey of previous studies}

Early studies of tax effort up to Piancastelli (2001) focussed on relating tax revenue to the various tax bases, so that tax effort was a measure of the degree to which the bases were being exploited. Later studies have included many more variables, including political and institutional variables, which improve the goodness of fit in explaining the actual tax revenue of countries, but make the meaning of tax effort difficult, as argued above.

\subsubsection{First generation studies}

Lotz and Morss (1967) were the first to measure the tax effort of countries taking a sample of 72 developed and developing countries for an average 
of years in the early $1960 \mathrm{~s}^{3}$. They compare the actual tax ratio of countries with the ratios predicted from cross-section regressions relating the tax ratio to the level of per capita gross national product (GNP) and the share of exports and imports in GNP. Tax effort is measured as the percentage difference in the actual tax ratio minus the predicted tax ratio ${ }^{4}$. The influence of per capita GNP is estimated both separately and jointly with the trade share. Both per capita income and the trade share are significant, but the tax effort ranking differs significantly when the trade share is introduced.

Shin (1969) takes a sample of 47 developed and developing countries for the years 1963-65 and adds three other variables to per capita GNP and the share of trade in GNP to explain differences in countries' tax ratio. They are: the 'agricultural income ratio as a measure of industrialisation, commercialisation and urbanisation'; the rate of change of prices, and the growth of population. The size of the agricultural sector is expected to have a negative effect on the tax ratio because of a smaller 'surplus' to tax. Inflation is expected to have a positive effect on the tax ratio if the tax system is progressive and pushes individuals into higher tax brackets, and also increases profits. Population growth is expected to reduce the tax ratio by increasing the population dependency rate leading to more tax exemptions. For the 47 countries as a whole, the statistically significant variables turn out to be per capita GNP; the agricultural income ratio and population increase $^{5}$. Tax effort, as in Lotz and Morss, is measured by the percentage deviation of the actual tax ratio from the predicted tax ratio.

Bahl (1971) takes 49 countries over the period 1966-1968 and uses three main variables to explain tax ratio differences, namely the size of the foreign trade sector measured by the export ratio, the import ratio, and the export plus import ratio; the stage of development as measured both by per capita income and the share of agriculture in GNP, and the sectoral composition of value-added measured by the share of the mining sector in GNP. The export share and the mining share in GNP are highly correlated. Tax effort in this paper is measured as the ratio of the actual tax ratio to the

3 Studies prior to this focussed on explaining tax revenue shares across countries, rather than tax effort itself. See Bahl (1971) for a survey.

4 In many later studies, tax effort is measured by the ratio of the actual tax ratio to the predicted ratio.

5 For 16 high-income countries, none of the variables are significant. For 31 low-income countries, the agricultural income ratio and price inflation are significant at the 95 percent confidence level, and population growth at the 90 percent level. 
predicted tax ratio ${ }^{6}$. A country with a ratio above unity is considered to be making a 'good effort'.

Chelliah et al. (1975) basically use the same equation as Bahl (1971). They take 47 countries over the period 1969-1971 and use as independent variables: per capita non-export income; the percentage contribution of the mining sector to GNP; the contribution of non-mineral exports to GNP, and the share of agriculture in GNP - with the variables used in five different combinations. The best fit with an $r^{2}$ of 0.442 comes from relating the tax ratio to the share of mining in GNP (positive) and the share of agriculture in GNP (negative). Twenty three countries have a tax effort greater than unity and twenty four less than unity.

Tait et al. (1979) update the study of Chelliah et al. (1975) using the same equations and the same 47 countries over the period 1972-1977. The authors also use a new sample of 63 developing countries. The authors dislike the term 'tax effort' and prefer to label their results 'international tax comparison indices'. The rankings using the same five equations of Chelliah et al. (1975) are all quite stable. The preferred equation for making 'international tax comparison indices' is:

$$
T / G N P=9.99-0.0008\left(Y_{p}-X_{p}\right)+0.407\left(N_{y}\right)+0.194\left(X_{y}\right): r^{2}=0.413
$$

where $\left(Y_{p}-X_{p}\right)$ is per capita non-export income; $N_{y}$ is the share of minerals in GNP, and $X_{y}$ is the share of non-mineral exports in GNP (t-statistics in brackets). Note that still a lot of difference in the tax ratio between countries is left unexplained.

Piancastelli (2001) estimates a panel fixed-effects model for 75 countries over the period 1985 to 1995 giving 825 observations The tax ratio and tax effort are estimated from an equation with the log of per capita GDP $(P C Y)$; the share of trade in $G D P(X+M) / G D P$, and the share of agriculture in $G D P(A / G D P)$ as the independent variables. The estimated equation is:

$$
\begin{aligned}
\ln T / Y= & 1.742+0.102(\ln P C Y)+0.158[\ln (X+M)) / G D P]-0.113[\ln (A / G D P)] \\
& (5.43)(3.69)
\end{aligned}
$$

6 In all subsequent papers, tax effort is measured in this way, not by the percentage difference in the actual and predicted tax ratio. 
with t-statistics in brackets. The correlation coefficient is 0.838 which is much higher than in the studies of Chelliah et al. (1975) and Tait et al. (1979). There is also a higher proportion of countries with a good tax effort with 41 countries with a tax effort ratio greater than unity, and 34 less than unity. Latin America does particularly badly with only 4 out of 17 countries with a ratio greater than unity.

\subsubsection{Second generation studies}

Gupta (2007) at the IMF was the first ${ }^{7}$ to add variables not related to the tax bases of developing countries - namely aid as a percentage of GDP and an index of corruption - along with the traditional variables of per capita income; agriculture's share of GDP, and imports as a share of GDP (the export share is not considered). The model is applied to a panel of 105 countries over the period 1980 to 2004 using random and fixed effects estimation, but without using the Hausman test to discriminate between the two. Per capita income is the most significant variable, but is more important in high-income countries than in low-income countries. Tax effort indices are constructed, but because of the inclusion of a corruption index, the measures of tax effort needs to be treated with caution because corruption would be a possible explanation of why the tax ratio differs between countries, not a measure of tax effort itself, as explained earlier.

Le et al. (2012) also include a measure of corruption and bureaucracy in their study of 110 developed and developing economies over the period 1994 to 2009 using pooled time series/cross section data. Population growth and a measure of the shadow economy are also included along with the traditional variables of per capita income; the share of agriculture in GDP, and the share of trade in GDP. All the variables are significant except per capita income when the measure of bureaucracy is included in the equation, which is a strange result. South Africa is estimated to have the highest tax effort and Switzerland the lowest, but again the same caveat applies that corruption and bureaucracy may explain differences in the tax ratio between countries but is not a measure of effort itself. 
The study by Dioda (2012) of 32 Latin American and Caribbean countries over the period 1990 to 2009 contains even more institutional and other variables in addition to the traditional tax bases, including an index of civil liberties and political rights; political stability; urbanisation; secondary school enrolment, and the size of the shadow economy. All the institutional variables are significant, but are explanations of differences in tax revenues between countries, not of tax effort related to the bases of tax revenue. ${ }^{8}$ If all tax revenue could be explained by a combination of economic and institutional variables, the concept of tax effort would lose meaning.

\section{The model}

We have chosen to take six main individual independent variables to explain the tax performance of countries over the period 1996-2015, all in logarithms for the reason mentioned earlier. They are: the per capita income of countries $(P C Y)$ as a measure of the capacity of individuals to pay tax; the share of trade in GDP $[(M+X) / Y]$ (where $M$ is imports and $X$ is exports) as a measure of the capacity of a country to tax trade; the share of industry (I/GDP), agriculture (A/GDP) and services(S/GDP) in GDP as a measure of the capacity to tax profits and land, and the degree of monetisation of an economy measured by $\mathrm{M} 2$ money as a percentage of GDP $(\mathrm{M} / G D P)^{9}$. The basic equation to be estimated is therefore:

$$
\begin{aligned}
& \left.\ln (T / G D P)=a+b_{1}(\ln P C Y)+b_{2}[\ln (X+M) / G D P)\right\}+ \\
& +b_{3}\left[(\ln (I / G D P)]+b_{4}[\ln (S / G D P)]+b_{5}[\ln (A / G D P)]+b_{6}[\ln (M / G D P)]+e\right.
\end{aligned}
$$

where $e$ is a stochastic error term. The expected signs of the per capita income variable, the trade variable and the broad money variable are positive, but the signs on the variables reflecting the structure of economies are ambiguous depending on the difficulty or otherwise of taxing the different

8 There are other recent studies explaining differences in tax revenue, but quite rightly do not use the results to measure tax effort e.g. Mahdavi (2008) and Rodriguez (2018).

$9 \mathrm{M} 2$ money consists of central government national currency holdings, other financial corporations, State and local governments, Public non-financial corporations, other resident sector, non-residents national currency holdings. 
sectors. Agriculture and a large petty service sector in an economy may be difficult to tax, in which case the coefficients would be negative.

Table 2 Tax effort using pooled data (1996-2015)

\begin{tabular}{lr|r|r|r|r|r}
\hline Independent Variables & $\mathbf{( 1 )}$ & $\mathbf{( 2 )}$ & $\mathbf{( 3 )}$ & $\mathbf{( 4 )}$ & $\mathbf{( 5 )}$ & $\mathbf{( 6 )}$ \\
\hline Ln & $0.11^{* * *}$ & & & $0.11^{* * *}$ & $0.14^{* * *}$ & $0.11^{* * *}$ \\
(GDP per capita) & $(0.01)$ & & & $(0.01)$ & $(0.01)$ & $(0.01)$ \\
\hline Ln & & $0.25^{* * *}$ & & $0.22^{* *}$ & $0.22^{* * *}$ & $0.22^{* * *}$ \\
(Trade/GDP) & & $(0.02)$ & & $(0.02)$ & $(0.01)$ & $(0.01)$ \\
\hline Ln & & & $0.11^{* * *}$ & $0.12^{* * *}$ & $0.11^{* * *}$ & $0.11^{* * *}$ \\
(Broad Money/GDP) & & & $(0.03)$ & $(0.02)$ & $(0.02)$ & $(0.02)$ \\
\hline Ln & & & & $0.07^{* * *}$ & $0.07^{* * *}$ & $0.12^{* * *}$ \\
(Agriculture/GDP) & & & & $(0.02)$ & $(0.02)$ & $(0.02)$ \\
\hline Ln & & & & & $-0.05^{*}$ & $0.06^{* *}$ \\
(Industry/GDP) & & & & & $(0.03)$ & $(0.02)$ \\
\hline Ln & & & & & & $0.57^{* * *}$ \\
(Services/GDP) & & & & & & $(0.05)$ \\
\hline Constant & $-2.78^{* * *}$ & $-1.72^{* * *}$ & $-1.48^{* * *}$ & $-2.51^{* * *}$ & $-2.59^{* * *}$ & $-1.77^{* * *}$ \\
& $(0.05)$ & $(0.01)$ & $(0.05)$ & $(0.07)$ & $(0.09)$ & $(0.11)$ \\
\hline Diagnostics & & & & & & \\
\hline No. of observations & 1121 & 1121 & 1121 & 1121 & 1121 & 1121 \\
\hline$r^{2}$ & 0.23 & 0.13 & 0.04 & 0.35 & 0.35 & 0.40 \\
\hline \multirow{2}{*}{ Functional form } & $\mathrm{F}=6.36$ & $\mathrm{~F}=5.42$ & $\mathrm{~F}=12.41$ & $\mathrm{~F}=3.79$ & $\mathrm{~F}=3.41$ & $\mathrm{~F}=1.78$ \\
& $\mathrm{P}=0.00$ & $\mathrm{P}=0.00$ & $\mathrm{P}=0.00$ & $\mathrm{P}=0.00$ & $\mathrm{P}=0.02$ & $\mathrm{P}=0.15$ \\
\hline Normality & $\mathrm{W}=0.95$ & $\mathrm{~W}=0.99$ & $\mathrm{~W}=0.99$ & $\mathrm{~W}=0.98$ & $\mathrm{~W}=0.98$ & $\mathrm{~W}=0.98$ \\
& $\mathrm{P}=0.00$ & $\mathrm{P}=0.00$ & $\mathrm{P}=0.00$ & $\mathrm{P}=0.00$ & $\mathrm{P}=0.00$ & $\mathrm{P}=0.00$ \\
\hline
\end{tabular}

Notes: The numbers in parentheses are robust standard errors. ${ }^{* * *} p<0.01$, ${ }^{* *} p<0.05,{ }^{*} p<0.1$. Functional Form is measured by the Ramsey RESET test. Normality is measured by the Shapiro-Wilk W test. All regressions include 59 country observations.

Three estimation techniques are used for comparison. First, we use a pooled time series/cross section estimator giving 1,121 observations for 59 countries over the period 1996 to 2015. Secondly, we apply panel estimation to the data, and test for random versus fixed effects. Thirdly, a cross section estimator is used to even out cyclical fluctuations in the data. In all cases, we first test individually the significance of per capita income, the trade ratio and the broad money ratio, because these are potentially the most likely variables to determine tax revenue. To these variables, we then add individually the variables reflecting the structure of production, 
namely, the share of agriculture, industry, and services in GDP, giving six equations in all. All the equations are estimated using robust standard errors to allow for heteroscedasticity. The results are shown in Tables 2, 3 and 4 , respectively.

Table 3 Tax effort using panel data with fixed effects (1996-2015)

\begin{tabular}{|c|c|c|c|c|c|c|}
\hline Independent Variables & (1) & (2) & (3) & (4) & (5) & (6) \\
\hline $\begin{array}{l}\text { Ln } \\
\text { (GDP per capita) }\end{array}$ & $\begin{array}{r}0.03^{* *} \\
(0.01)\end{array}$ & & & $\begin{array}{r}0.06^{* * *} \\
(0.01)\end{array}$ & $\begin{array}{r}0.06^{* *} \\
(0.02)\end{array}$ & $\begin{array}{l}0.05^{* *} \\
(0.02)\end{array}$ \\
\hline $\begin{array}{l}\text { Ln } \\
\text { (Trade /GDP) }\end{array}$ & & $\begin{array}{r}0.13^{* * * *} \\
(0.03)\end{array}$ & & $\begin{array}{l}0.15^{* *} \\
(0.03)\end{array}$ & $\begin{array}{r}0.16^{* * *} \\
(0.03)\end{array}$ & $\begin{array}{r}0.17^{* * * *} \\
(0.03)\end{array}$ \\
\hline $\begin{array}{l}\text { Ln } \\
\text { (Broad Money / GDP) }\end{array}$ & & & $\begin{array}{l}0.06^{* *} \\
(0.02)\end{array}$ & $\begin{array}{l}0.06^{* *} \\
(0.02)\end{array}$ & $\begin{array}{l}0.05^{* *} \\
(0.02)\end{array}$ & $\begin{array}{l}0.05^{* *} \\
(0.02)\end{array}$ \\
\hline $\begin{array}{l}\text { Ln } \\
\text { (Agriculture /GDP) }\end{array}$ & & & & $\begin{array}{l}0.11^{* *} \\
(0.05)\end{array}$ & $\begin{array}{l}0.11^{* *} \\
(0.04)\end{array}$ & $\begin{array}{r}0.13^{* * *} \\
(0.05)\end{array}$ \\
\hline $\begin{array}{l}\text { Ln } \\
\text { (Industry /GDP) }\end{array}$ & & & & & $\begin{array}{l}-0.05 \\
(0.04)\end{array}$ & $\begin{array}{l}-0.01 \\
(0.05)\end{array}$ \\
\hline $\begin{array}{l}\text { Ln } \\
\text { (Services /GDP) }\end{array}$ & & & & & & $\begin{array}{l}0.22^{* *} \\
(0.08)\end{array}$ \\
\hline Constant & $\begin{array}{r}-2.10^{* * *} \\
(0.13)\end{array}$ & $\begin{array}{r}-1.77^{* * * *} \\
(0.01)\end{array}$ & $\begin{array}{r}-1.71 * * * * \\
(0.01)\end{array}$ & $\begin{array}{r}-1.90^{* * *} \\
(0.31)\end{array}$ & $\begin{array}{r}-1.94^{* * *} \\
(0.12)\end{array}$ & $\begin{array}{r}-1.65^{* * *} \\
(0.17)\end{array}$ \\
\hline \multicolumn{7}{|l|}{ Diagnostics } \\
\hline No. of observations & 1121 & 1121 & 1121 & 1121 & 1121 & 1121 \\
\hline$r^{2}$ & 0.24 & 0.13 & 0.04 & 0.16 & 0.16 & 0.19 \\
\hline Functional form & $\begin{array}{l}F=5.10 \\
P=0.02\end{array}$ & $\begin{array}{l}F=3.34 \\
P=0.07\end{array}$ & $\begin{aligned} F & =5.11 \\
P & =0.02\end{aligned}$ & $\begin{array}{r}F=7.10 \\
P=0.00\end{array}$ & $\begin{array}{l}F=5.94 \\
P=0.02\end{array}$ & $\begin{array}{l}F=13.2 \\
P=0.9\end{array}$ \\
\hline Normality & $\begin{array}{l}W=0.98 \\
P=0.00\end{array}$ & $\begin{array}{l}W=0.99 \\
P=0.00\end{array}$ & $\begin{array}{l}W=0.99 \\
P=0.00\end{array}$ & $\begin{array}{l}W=0.97 \\
P=0.00\end{array}$ & $\begin{array}{l}W=0.99 \\
P=0.00\end{array}$ & $\begin{array}{l}W=0.99 \\
P=0.00\end{array}$ \\
\hline Hausman & $\begin{array}{r}x^{2}(1)=8.55 \\
P=0.00\end{array}$ & $\begin{aligned} x^{2}(1) & =2.3 \\
P & =0.13\end{aligned}$ & $\begin{array}{r}x^{2}(1)=1.6 \\
P=0.21\end{array}$ & $\begin{aligned} x^{2}(1) & =17.27 \\
P & =0.00\end{aligned}$ & $\begin{aligned} x^{2}(1) & =17.98 \\
P & =0.00\end{aligned}$ & $\begin{array}{r}x^{2}(1)=19.56 \\
P=0.00\end{array}$ \\
\hline
\end{tabular}

Notes: The numbers in parentheses are robust standard errors. ${ }^{* * *} p<0.01,{ }^{* *} p<0.05,{ }^{*} p<0.1$. Functional Form is measured by the Ramsey RESET test. Normality is measured by the Shapiro-Wilk W test. All regressions include 59 country observations.

In Table 2, using pooled data, per capita income is significant on its own, and doesn't lose its significance when combined with other variables. It is a robust variable with an elasticity of just over 0.1 . The trade ratio is also significant by itself and when other variables are added. Its elasticity is just over 0.2 . Likewise, broad money is statistically significant and robust to the 
addition of other variables, with an elasticity of just over 0.1 in the full equation. The shares of agriculture, industry and services in GDP are all significantly positive in the full model, but the service sector has by far the highest elasticity. The test statistics for functional form and the distribution of the error term are both passed, so we can have some confidence in the results.

Table 4 Tax effort using cross sectional data (1996-2015)

\begin{tabular}{lrrrrrrr}
\hline Independent Variables & $\mathbf{( 1 )}$ & $\mathbf{( 2 )}$ & $\mathbf{( 3 )}$ & $\mathbf{( 4 )}$ & $\mathbf{( 5 )}$ & $\mathbf{( 6 )}$ \\
\hline Ln & $0.11^{* * *}$ & & & $0.13^{* * *}$ & $0.14^{* * *}$ & $0.11^{* * *}$ \\
(GDP per capita) & $(0.03)$ & & & $(0.05)$ & $(0.05)$ & $(0.04)$ \\
\hline Ln & & $0.25^{* * *}$ & & $0.22^{* * *}$ & $0.22^{* * *}$ & 0.22 \\
(Trade/GDP) & & $(0.06)$ & & $(0.06)$ & $(0.06)$ & $(0.14)$ \\
\hline Ln & & $0.25^{*}$ & 0.15 & 0.14 & 0.14 \\
(Broad Money/GDP) & & & $(0.13)$ & $(0.13)$ & $(0.13)$ & $(0.12)$ \\
\hline Ln & & & & 0.07 & 0.06 & 0.12 \\
(Agriculture/GDP) & & & & $(0.09)$ & $(0.09)$ & $(0.09)$ \\
\hline Ln & & & & & -0.07 & 0.07 \\
(Industry/GDP) & & & & & $(0.134)$ & $(0.13)$ \\
\hline Ln & & & & & & $0.62^{* * *}$ \\
(Services/GDP) & & & & & $(0.19)$ \\
\hline Constant & $-2.80^{* * * *}$ & $-1.77^{* * *}$ & $-1.37^{* * *}$ & $-2.47^{* * *}$ & $2.58^{* * *}$ & $-1.70^{* * *}$ \\
\hline Diagnostics & $(0.27)$ & $(0.05)$ & $(0.23)$ & $(0.36)$ & $(0.43)$ & $-(0.57)$ \\
\hline No. of observations & & & & & & \\
\hline$r^{2}$ & 59 & 59 & 59 & 59 & 59 & 59 \\
\hline Functional form & 0.27 & 0.14 & 0.05 & 0.39 & 0.39 & 0.45 \\
\hline Normality & $\mathrm{F}=0.34$ & $\mathrm{~F}=0.20$ & $\mathrm{~F}=0.28$ & $\mathrm{~F}=0.45$ & $\mathrm{~F}=0.44$ & $\mathrm{~F}=0.13$ \\
\hline & $\mathrm{P}=0.79$ & $\mathrm{P}=0.89$ & $\mathrm{P}=0.89$ & $\mathrm{P}=0.70$ & $\mathrm{P}=0.72$ & $\mathrm{P}=0.9$ \\
\hline W=0.95 & $\mathrm{W}=0.98$ & $\mathrm{~W}=0.98$ & $\mathrm{~W}=0.98$ & $\mathrm{~W}=0.98$ & $\mathrm{~W}=0.98$ \\
& $\mathrm{P}=0.01$ & $\mathrm{P}=0.52$ & $\mathrm{P}=0.61$ & $\mathrm{P}=0.54$ & $\mathrm{P}=0.50$ & $\mathrm{P}=0.71$ \\
\hline
\end{tabular}

Notes: The numbers in parentheses are robust standard errors. ${ }^{* * *} p<0.01$, ${ }^{* *} p<0.05,{ }^{*} p<0.1$. All Variables are an average over the period. All regressions include 59 country observations. Functional Form is measured by the Ramsey RESET test. Normality is measured by the Shapiro-Wilk W test.

In Table 3, the use of panel data shows similar results. Applying the Hausman test, the fixed effects estimator is supported for all equations. Per capita income is always statistically significant, but with a much lower elasticity than with pooled data - between 0.03 and 0.06 . The trade ratio is always statistically significant but with a slightly lower elasticity than with the pooled data. Broad money is also significant but with a much 
lower elasticity than with the pooled data. The shares of agriculture and services in GDP are significantly positive, but the share of industry is not. The test statistics reject the null of omitted variable bias and a non-normal distribution of the error term.

In Table 4, the cross section results tell a rather different story. Per capita income and the trade ratio are statistically significant and show very similar elasticities to the pooled data, but broad money is not significant, and nor is the share of agriculture and industry in GDP. The share of services, however, is highly significant. Equation (6), which we use for estimating tax effort, passes the Ramsey Reset test for functional form, and the Shapiro-Wilk test for the normal distribution of the error term.

\section{Tax Effort - Results}

To estimate the tax effort of countries, we ignore the panel data estimating equations because of their low explanatory power, and use equation (6) from the pooled and cross section estimates in Tables 2 and 4, respectively. The results are shown in Tables 5 and 6 . The fitted values from the estimation equations show a close fit with the actual tax ratios of countries. From the pooled data, and cross section, estimates, the average fitted value is 16.59 percent compared with the actual tax ratio average of 17.09 percent. The rank correlation of tax effort measured from the pooled and cross section estimation equations is 0.97 .

The tax effort of countries is measured by the ratio of the actual tax ratio to the fitted value from the regressions. A ratio in excess of unity suggests a 'good' tax effort, and a ratio below one suggests a country is not using to the full its taxable capacity compared with comparator countries. From Table 5, which uses the pooled regressions, it can be seen that 34 countries have a 'good' tax effort with South Africa heading the list. From Table 6, which uses the cross section estimates, 32 countries have a 'good' tax effort, with South Africa again at the top ${ }^{10}$. Developing countries which show a 'good' tax effort include Botswana, Morocco, Turkey, Jordan, Kenya, Colombia, Indonesia, Uruguay, Tunisia, Chile, Venezuela, Cameroon, Zambia, Sierra Leone, Brazil, Bolivia, Peru, Ghana and Panama.

10 This is also found in the study by Le et al. with a tax effort ratio of 1.44. 
A tax effort ratio less than unity implies a poor tax effort by international standards of comparison. Switzerland turns out to be the worst performer. ${ }^{11}$ It has the potential tax ratio of 19.3 percent of GDP, based on the level of per capita income, trade share, structure of production and monetisation of the economy, but its actual tax/GDP ratio is only 9.43 percent. The worst performers among developing countries are Iran, Guatemala, Costa Rica, Dominican Republic, India, Paraguay, Mauritius, Thailand, Malaysia, Madagascar, Pakistan, Nepal, Philippines, Mexico, Argentina and El Salvador. Panama is on the margin with a tax effort ratio just above unity using estimates from the pooled regression and just below unity using the cross section estimates. Four of these countries - India, Pakistan, Malaysia and Mexico - are among the countries mentioned at the beginning which have both a low tax ratio and a relatively high debt ratio.

Table 5 Tax effort indices - full sample: pooled data estimates

\begin{tabular}{|c|c|c|c|c|c|c|c|}
\hline Countries & $\begin{array}{r}\text { Tax } \\
\text { Ratio } \\
\text { Actual } \\
(a)^{*}\end{array}$ & $\begin{array}{r}\text { Tax } \\
\text { Ratio } \\
\text { Fitted } \\
(b)^{* *}\end{array}$ & $\begin{array}{r}\text { Tax } \\
\text { Effort } \\
\text { Index } \\
(\mathrm{c}=\mathrm{a} / \mathrm{b})\end{array}$ & Countries & $\begin{array}{r}\text { Tax } \\
\text { Ratio } \\
\text { Actual } \\
(a)^{*}\end{array}$ & $\begin{array}{r}\text { Tax } \\
\text { Ratio } \\
\text { Fitted } \\
(\mathbf{b})^{* *}\end{array}$ & $\begin{array}{r}\text { Tax } \\
\text { Effort } \\
\text { Index } \\
(c=a / b)\end{array}$ \\
\hline South Africa & 25.237 & 14.802 & 1.705 & Ghana & 13.667 & 13.347 & 1.024 \\
\hline Denmark & 32.574 & 19.912 & 1.636 & Greece & 20.211 & 19.977 & 1.012 \\
\hline UK & 25.516 & 17.661 & 1.445 & Belize & 20.826 & 20.605 & 1.011 \\
\hline Norway & 26.558 & 18.671 & 1.422 & Panama & 21.537 & 21.516 & 1.001 \\
\hline Sweden & 27.889 & 19.706 & 1.415 & El Salvador & 12.333 & 12.522 & 0.985 \\
\hline Botswana & 20.621 & 14.947 & 1.380 & Argentina & 14.458 & 14.852 & 0.973 \\
\hline Morocco & 20.281 & 14.954 & 1.356 & Malta & 24.984 & 26.149 & 0.955 \\
\hline New Zealand & 27.142 & 20.668 & 1.313 & Mexico & 14.826 & 15.683 & 0.945 \\
\hline Australia & 22.979 & 18.239 & 1.260 & Philippines & 13.298 & 14.336 & 0.928 \\
\hline Turkey & 19.884 & 15.854 & 1.254 & Nepal & 10.597 & 11.458 & 0.925 \\
\hline Italy & 22.753 & 18.533 & 1.228 & Pakistan & 10.667 & 11.767 & 0.906 \\
\hline Jordan & 18.753 & 15.591 & 1.203 & Netherlands & 21.232 & 24.045 & 0.883 \\
\hline Kenya & 16.281 & 13.587 & 1.198 & Madagascar & 11.158 & 12.649 & 0.882 \\
\hline Colombia & 15.353 & 13.026 & 1.179 & Mauritius & 16.963 & 19.553 & 0.868 \\
\hline Ireland & 25.137 & 21.726 & 1.157 & Thailand & 14.716 & 16.979 & 0.867 \\
\hline
\end{tabular}

11 This is also found by Le et.a.l. (2012) with a tax effort ratio of 0.56 . 
Table 5 (continuation)

\begin{tabular}{l|r|r|r}
\hline Countries & $\begin{array}{r}\text { Tax } \\
\text { Ratio } \\
\text { Actual } \\
(\mathbf{a})^{*}\end{array}$ & $\begin{array}{r}\text { Tax } \\
\text { Ratio } \\
\text { Fitted } \\
(\mathbf{b})^{* *}\end{array}$ & $\begin{array}{r}\text { Tax } \\
\text { Effort } \\
\text { Index } \\
(\mathbf{c = a} / \mathbf{b})\end{array}$ \\
\hline Finland & 21.705 & 19.339 & 1.122 \\
\hline Indonesia & 13.649 & 12.204 & 1.118 \\
\hline Uruguay & 17.979 & 16.080 & 1.118 \\
\hline Tunisia & 19.405 & 17.362 & 1.118 \\
\hline Chile & 17.226 & 15.442 & 1.116 \\
\hline Portugal & 21.158 & 19.292 & 1.097 \\
\hline Venezuela & 15.205 & 13.896 & 1.094 \\
\hline Cameroon & 13.965 & 12.778 & 1.093 \\
\hline Iceland & 24.200 & 22.226 & 1.089 \\
\hline Zambia & 15.035 & 13.890 & 1.082 \\
\hline Romania & 17.342 & 16.236 & 1.068 \\
\hline Sierra Leone & 8.509 & 7.994 & 1.064 \\
\hline Brazil & 14.437 & 13.609 & 1.061 \\
\hline Bolivia & 14.930 & 14.193 & 1.052 \\
\hline Peru & 14.758 & 14.191 & 1.040 \\
\hline & Full Sample Average Values:
\end{tabular}

\begin{tabular}{l|r|r|r}
\hline Countries & $\begin{array}{r}\text { Tax } \\
\text { Ratio } \\
\text { Actual } \\
(\mathbf{a})^{*}\end{array}$ & $\begin{array}{r}\text { Tax } \\
\text { Ratio } \\
\text { Fitted } \\
(\mathbf{b})^{* *}\end{array}$ & $\begin{array}{r}\text { Tax } \\
\text { Effort } \\
\text { Index } \\
(\mathbf{c = a} \mathbf{b})\end{array}$ \\
\hline Malaysia & 15.547 & 18.048 & 0.861 \\
\hline Paraguay & 13.386 & 15.884 & 0.843 \\
\hline India & 9.825 & 11.906 & 0.825 \\
\hline Spain & 14.679 & 17.854 & 0.822 \\
\hline Japan & 12.332 & 15.211 & 0.811 \\
\hline Dominican Rep. & 13.311 & 16.522 & 0.806 \\
\hline Korea & 14.068 & 18.144 & 0.775 \\
\hline Costa Rica & 13.789 & 18.064 & 0.763 \\
\hline Guatemala & 11.105 & 15.067 & 0.737 \\
\hline United States & 10.832 & 15.081 & 0.718 \\
\hline Canada & 13.242 & 19.904 & 0.665 \\
\hline Germany & 11.242 & 17.038 & 0.660 \\
\hline Iran & 7.553 & 13.042 & 0.579 \\
\hline Switzerland & 9.432 & 19.624 & 0.481 \\
\hline 17.09 (Actual); 16.59(Fitted) & & \\
\hline
\end{tabular}

Notes: * Total Tax Revenue / GDP.

** Derived from equation 6, Pooled Time Series Cross-Section results in Table 2.

Table 6 Tax effort indices - full sample: cross section estimates

\begin{tabular}{|c|c|c|c|}
\hline Countries & $\begin{array}{r}\text { Tax } \\
\text { Ratio } \\
\text { Actual } \\
(a)^{*}\end{array}$ & $\begin{array}{r}\text { Tax } \\
\text { Ratio } \\
\text { Fitted } \\
(\mathbf{b})^{* *}\end{array}$ & $\begin{array}{r}\text { Tax } \\
\text { Effort } \\
\text { Index } \\
(\mathrm{c}=\mathrm{a} / \mathrm{b})\end{array}$ \\
\hline South Africa & 25.237 & 14.876 & 1.696 \\
\hline Denmark & 32.574 & 19.877 & 1.639 \\
\hline Belize & 20.826 & 14.305 & 1.456 \\
\hline UK & 25.516 & 17.743 & 1.438 \\
\hline Norway & 26.558 & 18.741 & 1.417 \\
\hline Sweden & 27.889 & 19.784 & 1.410 \\
\hline Botswana & 20.621 & 14.842 & 1.389 \\
\hline
\end{tabular}

\begin{tabular}{l|r|r|r}
\hline Countries & $\begin{array}{r}\text { Tax } \\
\text { Ratio } \\
\text { Actual } \\
(\mathbf{a})^{*}\end{array}$ & $\begin{array}{r}\text { Tax } \\
\text { Ratio } \\
\text { Fitted } \\
(\mathbf{b})^{* *}\end{array}$ & $\begin{array}{r}\text { Tax } \\
\text { Effort } \\
\text { Index } \\
(\mathbf{c = a} / \mathbf{b})\end{array}$ \\
\hline Ghana & 13.667 & 13.454 & 1.016 \\
\hline Peru & 14.758 & 14.568 & 1.013 \\
\hline Greece & 20.211 & 20.461 & 0.988 \\
\hline Panama & 21.537 & 21.914 & 0.983 \\
\hline El Salvador & 12.333 & 12.562 & 0.982 \\
\hline Argentina & 14.458 & 15.128 & 0.956 \\
\hline Malta & 24.984 & 26.572 & 0.940 \\
\hline
\end{tabular}


Table 6 (continuation)

\begin{tabular}{|c|c|c|c|c|c|c|c|}
\hline Countries & $\begin{array}{r}\text { Tax } \\
\text { Ratio } \\
\text { Actual } \\
(a)^{*}\end{array}$ & $\begin{array}{r}\text { Tax } \\
\text { Ratio } \\
\text { Fitted } \\
(\mathbf{b})^{* *}\end{array}$ & $\begin{array}{r}\text { Tax } \\
\text { Effort } \\
\text { Index } \\
(\mathbf{c}=\mathrm{a} / \mathrm{b})\end{array}$ & Countries & $\begin{array}{r}\text { Tax } \\
\text { Ratio } \\
\text { Actual } \\
(a)^{*}\end{array}$ & $\begin{array}{r}\text { Tax } \\
\text { Ratio } \\
\text { Fitted } \\
(b)^{* *}\end{array}$ & $\begin{array}{r}\text { Tax } \\
\text { Effort } \\
\text { Index } \\
(\mathrm{c}=\mathrm{a} / \mathrm{b})\end{array}$ \\
\hline Morocco & 20.281 & 14.833 & 1.367 & Mexico & 14.826 & 15.791 & 0.939 \\
\hline New Zealand & 27.142 & 20.952 & 1.295 & Philippines & 13.298 & 14.251 & 0.933 \\
\hline Turkey & 19.884 & 15.868 & 1.253 & Nepal & 10.597 & 11.409 & 0.929 \\
\hline Australia & 22.979 & 18.587 & 1.236 & Pakistan & 10.667 & 11.708 & 0.911 \\
\hline Italy & 22.753 & 18.792 & 1.211 & Madagascar & 11.158 & 12.471 & 0.895 \\
\hline Jordan & 18.753 & 15.521 & 1.208 & Malaysia & 15.547 & 17.663 & 0.880 \\
\hline Kenya & 16.281 & 13.681 & 1.190 & Thailand & 14.716 & 16.856 & 0.873 \\
\hline Colombia & 15.353 & 12.959 & 1.185 & Netherlands & 21.232 & 24.358 & 0.872 \\
\hline Ireland & 25.137 & 22.029 & 1.141 & Mauritius & 16.963 & 19.808 & 0.856 \\
\hline Finland & 21.705 & 19.250 & 1.128 & Paraguay & 13.386 & 15.746 & 0.850 \\
\hline Indonesia & 13.649 & 12.188 & 1.120 & Spain & 14.679 & 17.919 & 0.819 \\
\hline Chile & 17.226 & 15.398 & 1.119 & India & 9.825 & 11.994 & 0.819 \\
\hline Tunisia & 19.405 & 17.362 & 1.118 & Japan & 12.332 & 15.553 & 0.793 \\
\hline Uruguay & 17.979 & 16.088 & 1.118 & Dominican Rep. & 13.311 & 16.902 & 0.788 \\
\hline Sierra Leone & 8.509 & 7.808 & 1.090 & Korea & 14.068 & 18.376 & 0.766 \\
\hline Cameroon & 13.965 & 12.817 & 1.090 & Costa Rica & 13.7895 & 18.2061 & 0.7574 \\
\hline Venezuela & 15.205 & 14.057 & 1.082 & Guatemala & 11.1054 & 15.1309 & 0.7340 \\
\hline Iceland & 24.200 & 22.400 & 1.080 & United States & 10.8316 & 15.2702 & 0.7093 \\
\hline Portugal & 21.158 & 19.718 & 1.073 & Germany & 11.2421 & 16.9437 & 0.6635 \\
\hline Zambia & 15.035 & 14.192 & 1.059 & Canada & 13.2421 & 20.5320 & 0.6450 \\
\hline Brazil & 14.437 & 13.803 & 1.046 & Iran & 7.5526 & 12.9470 & 0.5833 \\
\hline Bolivia & 14.930 & 14.305 & 1.044 & Switzerland & 9.4316 & 19.3840 & 0.4866 \\
\hline Romania & 17.342 & 16.688 & 1.039 & & & & \\
\hline
\end{tabular}

Notes: * Total Tax Revenue /GDP.

** Derived from equation 6, Cross Section estimates results in Table 4.

\section{Policy Implications}

For countries with a weak tax effort, the policy implications are clear. Every effort needs to be made to expand the tax base and to apply and en- 
force rates of tax which bring more yield consistent with the traditional canons of taxation: equity, efficiency and administrative convenience. In many developing countries, the tax system is neither equitable nor efficient, and is administratively cumbersome. Avoidance (legal) and evasion (illegal) are rife. Equity requires a comprehensive definition of income and non-discrimination between income sources. A major deficiency of tax systems all over the world, and particularly in developing countries, is that there is no single comprehensive tax on all income. Typically there is a 'cedular' system with separate taxes and tax rates on different sources of income. Wage and salary earners tend to be discriminated against vis-à-vis both owners of capital and property, and against the self-employed such as professional people and small-traders. An equitable system should also be such that it discourages luxury consumption and makes it difficult to avoid and evade taxation.

Taxable capacity is not measured by income alone, but also by wealth. Equity therefore also requires the taxation of wealth. A major deficiency of the tax system of many developing countries is the anonymity of wealth ownership, which precludes taxing wealth.

These observations and beliefs were common features of the tax advice that the famous Cambridge economist, Nicholas Kaldor, gave to all the developing countries that he advised between 1956 and 1976 ${ }^{12}$, which led to five major recommendations for most countries. First, that all income (including capital gains) should be aggregated and taxed in the same way, at a progressive rate, but not exceeding a top marginal rate of 50 percent. Secondly, there should be a progressive expenditure tax levied on rich individuals imposed where income tax leaves off. Thirdly, the imposition of a wealth tax. Fourthly, the introduction of a gifts tax. And lastly, the simplification of corporation tax to be imposed at a single rate. Above all, the entire tax system should be self-reinforcing and self-checking. Every taxpayer would have a code number and all property transfers would have to disclose the code number of the transferer and transferee. By this system, attempts by a taxpayer to avoid one tax would increase the liability for another, and the attempt of one party to conceal a transfer would increase the tax liability of the other party. In addition, to tackle tax evasion and avoidance, Kaldor recommended the training of a corps d'elite of highly (1961); British Guiana (now Guyana)(1962); Turkey(1963); Iran(1966); Venezuela(1976). 
paid tax officials (on French lines) immune from the temptation of bribes, deriving instead pride and satisfaction from their social status as highly paid state officials. All these Kaldor recommendations are as relevant today as they were when Kaldor was giving advice to developing countries over fifty years ago. Individual countries, of course, need to decide where their own priorities lie.

Most of Kaldor's advice, however, related to income and wealth taxes. Much less was said about trade taxes and taxes on different sectors of an economy. Many countries today raise as much tax revenue from trade taxes as they do from income tax. With regard to trade, import taxes are to be preferred to export taxes which can reduce the incentive to produce. Import taxes, or tariffs, have the merit of not only raising revenue, but can also be used as a means of domestic protection or potential import substitution. Luxury imports should be taxed the highest not only because they are generally more price inelastic and will raise the most revenue, but also because they are egalitarian by taking proportionately more tax from the rich than the poor. Import taxes can also be applied further down the value chain by identifying imports that could easily be produced domestically with limited protection; for example, types of food imports or processed raw materials.

Taxes raised from different sectors of the economy - agriculture, mining, manufacturing and services - relate largely to the taxation of profits. Multinational corporations are notorious for avoiding tax by transfer pricing and the over-invoicing of imported inputs; also by the repatriation of profits. Greater surveillance and regulation of multinational corporations is required. Taxes on agriculture are difficult to apply without affecting the incentive to produce, but the taxation of unused or under-utilised land should be considered to raise revenue, and also as an incentive for greater land utilisation. Kaldor (1980) recommended a tax on the productive potential of land in many of the countries he advised, although it was invariably rejected by powerful vested interests.

Adrian Wood (2008), the Oxford economist, has suggested an ingenious scheme for raising more tax revenue by linking international aid to tax effort. For every extra dollar raised in tax, donors would collectively agree to give fifty cents extra in aid up to a fifty percent upper limit of the ratio of aid to taxation. This would give a strong incentive for countries with an aid to tax ratio below that limit to raise more taxation. 
All countries, especially developing countries, need tax revenue to provide public goods with positive externalities, and for social expenditure. Without public expenditure on health, education and infrastructure, the development process is thwarted. Kaldor's advice to developing countries was often ignored, but he was unapologetic. At the end of his book of Essays on tax advice to developing countries (Kaldor, 1980) he concludes rather dramatically: 'Progressive taxation is, in the end, the only alternative to complete expropriation through violent revolution'.

\section{References}

BAHL, R.W. A Regression Approach to Tax Effort and Tax Ratio Analysis. IMF Staff Papers, 18(3): 570-608, 1971.

BIRD, R.M. Assessing Tax Performance in Developing Countries: A Critical Review of the Literature. Finanzarchiv, 34 (2): 244-265, 1976.

BIRD, R.M.; MARTINEZ-VASQUES, J.; TORGLER, B. Societal Institutions and Tax Effort in Developing Countries. Working Paper 04-06, Andrew Young School of Policy Studies, Georgia State University, (1-49), 2004.

BIRD, R.M. Tax Effort in Developing Countries and High income Countries: The Impact of Corruption, Voice and Accountability. Economic Analysis and Policy, 38, p. 55-71, 2008.

BURGESS, R; STERN, N. Taxation and Development. Journal of Economic Literature, v. 31, i. 2, p. 391-413, 1993.

CANAVIRE-BACARREZA, G.; MARTINEZ-VAZQUEZ, J.; VULOVIC, V. Taxation and Economic Growth in Latin America, Inter-American Development Bank (IDB), 2013.

CHELLIAH, R.J. Trends in Taxation in Developing Countries. IMF Staff Papers, 18(2), p. 254331, 1971.

CHELLIAH, R.J.; BASS, H. J.; KELLEY, M. R. Tax Ratios and Tax Effort in Developing Countries 1969-1971. IMF Staff Papers, 22(1), p. 187-205, 1975.

CODY, D. Creating Fiscal Space. Finance and Development, 55(4), p. 23-28, 2018.

DAHLBY, B.; WILSON, L.S. Fiscal Capacity, Tax Effort, and Optimal Equalization Grants. Canadian Journal of Economics, 27 (3), p. 659-672, 1994.

DIODA, L. Structural Determinants of Tax Revenue in Latin America and the Caribbean 1990-2009, December (ECLAC), 2012.

EASTERLY, W; REBELO, S. Marginal Income Tax Rates and Economic Growth in Developing Countries. European Economic Review, 37, 1993.

GUPTA, A.S. Determinants of Tax Revenue Effort in Developing Countries. IMF Working Paper WP/07/1184, Washington DC: IMF, 2007.

IMF. Revenue Mobilisation in Developing Countries. Fiscal Affairs Division of the IMF, Washington 
DC: IMF, 2011.

KALDOR, N. Will Underdeveloped Countries Learn to Tax?. Foreign Affairs, v. 41, p. 410-419, 1963.

KALDOR, N. Reports on Taxation 11. London: Duckworth, 1980.

LE, T. M.; MORENO-DODSON, R.; BAYRAKTAR, N. Tax Capacity and tax Effort: Extended Cross-Country Analysis from 1994 to 2009. World Bank Policy Research Working Paper 6252, Washington: World Bank, 2012.

LEWIS, A.W. Development Planning, London: George, Allen and Unwin, 1966.

LOTZ, J. R.; MORSS, E. Measuring Tax Effort in Developing Countries. IMF Staff Papers, 14(4), p. 478-497, 1967.

MAHDAVI, S. The Level and Composition of Tax Revenue in Developing Countries: Evidence from Unbalanced Panel Data. International Review of Economics and Finance, v. 17, p. 607-617, 2008.

MOORE, M.; PRICHARD, W.; FJELDSTAD, O-H. Taxing Africa, London: Zed Books, 2018.

NANTOB, N. Y. Taxes and Economic Growth in Developing Countries: A Dynamic Panel Approach. MPRA - Munich Personal RePec Archive, No. 61346, p. 1-23, 2015.

PIANCASTELLI, M. Measuring Tax Effort of Developed and Developing Countries: Cross Country Panel Data Analysis 1985/95, IPEA (Brazil), 2001.

RODRIGUEZ, V. Tax Determinants Revisited: An Unbalanced Panel Data Analysis. Applied Economics, v. 21, i. 1, p. 1-24, 2018.

SHIN, K. International Differences in Tax Revenue. Review of Economics and Statistics, v. 51, i. 2, p. 213-230, 1969.

TAIT, A.; GRATZ, W.; EICHENGREEN, B. International Comparison of Taxation for Selected Developing Countries 1972-76, IMF Staff Papers, 21(1), p. 123-156, 1979.

THIRLWALL, A. P. Nicholas Kaldor, New York: New York University Press, 1987.

WOOD, A.How Donors Should Cap Aid to Africa, Financial Times, 14 September, 2008.

ZEE, H. H. Empirics of Cross Country Tax Revenue Comparisons. World Development, v. 24, i. 10 , p. 1659-1671, 1996.

\section{About the authors}

MarceloPiancastelli-marcelo.piancastelli@gmail.com

Institute for Applied Economic Research (Ipea), Brasilia, Brazil. ORCID: https://orcid.org/0000-0002-1573-9882.

Anthony Philip Thirlwall - a.p.thirlwall@kent.ac.uk

School of Economics, University of Kent, Cantebury, United Kingdom.

ORCID: https://orcid.org/0000-0002-1661-2218.

\section{About the article}

Submission received on October 11, 2019. Approved for publication on April 27, 2020. 